\title{
Türkiye Geleneksel ve Tamamlayıcı Tıp Merkezleri; Eğitim ve Uygulama İnovasyonu
}

\author{
Turkey Traditional and Complementary Medicine Centers; \\ Training and Application Innovation
}

\author{
Ahmet Yaser Müslümanoğlu' ${ }^{1}$ Kanat Tayfun ${ }^{2}$ \\ ${ }^{1}$ Sağlık Bilimleri Üniversitesi Bağcılar Eğitim ve Araştırma Hastanesi, Hastane Başhekimi, \\ Sağlık Bilimleri Üniversitesi Geleneksel ve Tamamlayıcı Tip Uygulama ve Araştırma Merkezi Müdürü, \\ Sağlık Bilimleri Üniversitesi Geleneksel ve Tamamlayıcı Tip Ana Bilim Dalı Başkanı, İstanbul \\ ${ }^{2}$ Sağlık Bilimleri Üniversitesi Bağcılar Eğitim ve Araştırma Hastanesi, \\ Hastane Geleneksel ve Tamamlayıı Tip Uygulama ve Araştırma Merkezi Sorumlu Hekimi, İstanbul \\ Yazışma Adresi / Correspondence: \\ Prof. Dr. Ahmet Yaser Müslümanoğlu \\ Merkez, Dr. Sadık Ahmet Cd, 34100 Bağcllar/İstanbul \\ E-mail: ymuslumanoglu56@hotmail.com \\ Orcid \\ Ahmet Yaser Müslümanoğlu : https://orcid.org/0000-0002-8691-0886 \\ Kanat Tayfun : https://orcid.org/0000-0002-5162-6797
}

Geliş Tarihi / Received : 19-09-2019 Kabul Tarihi / Accepted : 22-09-2019 Yayın Tarihi / Online Published: 30-09-2019

Müslümanoğlu A.Y., Tayfun K., Türkiye Geleneksel ve Tamamlayıcı Tıp Merkezleri; Eğitim ve Uygulama İnovasyonu,

J Biotechnol and Strategic Health Res. 2019;3:(Özel Sayı)1-12 DOI: bshr.622302

\footnotetext{
Özet

Geleneksel ve tamamlayıcı tıp insanlık tarihi kadar köklü bir geçmişe sahip olup 21.yüzyılın başında tüm dünyada tekrar popülarite kazanmıștır. Sadece geri kalmış ve gelişmekte olan ülkelerde değil sağlık sisteminde batı tıbbının baskın olduğu gelişmiş ülkelerde de kullanımı yaygınlaşmıștır. Geleneksel ve tamamlayıcı tıbbın yaygınlaşması ile tedavi standardizasyonu ve denetimi gerekliliği doğmustur. Dünya Sağlık Örgütü ilk defa 2000 yılında "Geleneksel Tip Araștırma ve Değerlendirme Metodolojileri Rehberi ",2014 yilında geleneksel tıbbın güvenli ve etkili kullanımını teşvik eden "Pekin Deklarasyonu”nu yayımlanmıștır. Ülkemiz de dünya ile eş zamanlı olarak 2014 yılında Geleneksel ve Tamaxmlayıcı Tip Uygulamaları Yönetmeliğini yürürlüğe koymuştur. Bu yönetmeliğe göre bakanlık tarafindan yalnızca hekimlere ve sadece kendi alanında uygulama yapmak üzere diș hekimlerine geleneksel ve tamamlayıcı tıp alanında uygulama yetkisi verilmiștir. 14 farklı alanda standardize eğitim tanımlanmış olup yetkili merkezler tarafından teorik ve pratik eğitim verilmektedir. Bundan sonraki süreçte geleneksel tıbbın sağlık sistemi ve batı tıbbı ile entegrasyonu, lisans ve yüksek lisans düzeyinde eğitim ve araştırmaların artması büyük bir gelişme olacaktır.

Anahtar Akupunktur, Fitoterapi, Geleneksel Tip

Traditional and complementary medicine has a long history as human history and has gained popularity all over the world at the beginning of the 21st century. Its use has become widespread not only in underdeveloped and developing countries but also in developed countries where western medicine is dominant in the health system. With the spread of traditional and complementary medicine, the need for standardization and control of treatment has emerged. In 2000, the World Health Organization published the "General Guidelines for Methodologies on Research and Evaluation of Traditional Medicine" and in 2014 the "Beijing Decleration", which promotes the safe and effective use of traditional medicine. At the same year with the world, Turkey Ministry of Health introduced the Regulation on Traditional and Complementary Medicine Practices in 2014. According to this regulation, only the physicians and the dentists are authorized to practice in the field of traditional and complementary medicine. Standardized training has been defined in 14 different fields and theoretical and practical training is provided by authorized centers. In the following period, the integration of traditional medicine with the health system and western medicine, and the increase of education and research at the undergraduate and graduate level will be a major development.

Keywords Acupuncture, Phytotherapy, Traditional Medicine
} 


\section{Giriş}

"Geleneksel ve tamamlayıcı tıp” Dünya Sağlık Örgütünce fiziksel ve ruhsal hastalıklardan korunma, bunlara tanı koyma, iyileştirme veya tedavi etmenin yanında sağlı̆̆ın iyi sürdürülmesinde de kullanılan, farklı kültürlere özgü teori, inanç ve tecrübelere dayalı, izahı yapılabilen veya yapılamayan bilgi, beceri ve uygulamaların bütünüdür. ${ }^{1}$

Benzer anlamlarda kullanılan "Tamamlayıcı tıp” veya “alternatif tıp" terimleri ülkelerin var olan resmi sağlık sistemlerinin dışında kalan, geleneksel sağlık uygulamalarını kapsamaktadır. Bir başka değişle konvansiyonel olarak uygulanan Batı tıbbının haricinde gerçekleştirilen toplumsal geleneklerden beslenen destekleyici tıbbi uygulama biçimlerine geleneksel, alternatif veya tamamlayıcı tıp denmektedir. Yani konvansiyonel tıbbın alanı haricindeki sağlık uygulamaları yoluyla tanımlanır. Tamamlayıcı tıp ise, ilave yarar sağladığına inanılan sağlık uygulamalarının konvansiyonel tıpla birlikte kullanılması sonucu kazandığı anlamdir. $^{2}$

Geleneksel ve tamamlayıcı tıp konusu yıllardan beri DSÖ Genel Kurullarının gündemine gelmektedir. Geleneksel Tıp Alanında Araştırma ve Eğitimin Geliştirilmesi (1977), Tibbi Bitkiler (1978), Geleneksel Tip (1987), Geleneksel Tip ve Tibbi Bitkiler (1988), Geleneksel Tip ve Modern Sağlık Hizmetleri $(1989,1991)$ başlıkları altında kararlar kabul edilmiştir. ${ }^{3}$ Bu sürede akupunktur ve bitkisel tedavileri konu alan birçok rapor yayımlanmıştır. " "Geleneksel Tıp Araştırma ve Değerlendirme Metodolojileri Rehberi (2000)" ve “Geleneksel Tip /Alternatif ve Tamamlayıcı Tibbın Dünyadaki Yasal Durumu (2001)” ile “DSÖ Geleneksel Tıp Stratejisi 2002-2005"adlı dokümanlar yayımlanmıştır. ${ }^{5,6,7}$

Pekin'de düzenlen Geleneksel Tip Kongresinin ardından geleneksel tıbbın güvenli ve etkili kullanımını teşvik eden "Pekin Deklarasyonu" yayımlandı. Deklarasyon, geleneksel tıbbın ulusal sağlık sistemlerine entegre edilmesi yönünde DSÖ üye ülkelerini adım atmaya davet etmiştir.
Geleneksel tıp hakkında ulusal politika oluşturulması, geleneksel ve bitkisel ilaçlarla ilgili ulusal mevzuat geliştirilmesi, geleneksel tıbbın temel sağlık hizmetleri kapsamında ele alınması ve geleneksel tıp uygulamaları için ulusal düzenlemelerle bu alanlarda araştırmaların yapılması için, üye ülkeler iş birliği yapmaya çağırmaktadır. Ayrıca konvansiyonel tıp ile geleneksel tıp mensupları arasında iletişimin güçlendirilmesi; sağlık çalışanlarına, tıp öğrencilerine ve ilgili araştırmacılara yönelik uygun eğitim programlarının yapılması gerektiğine vurgu yapılmaktadır. ${ }^{8,9} 2014$ yılında yayınlanan 2014-2023 DSÖ Geleneksel Tip Stratejisi raporunda bu uygulamaların sağlık hizmetleri sunumunda kullanımlarının yaygınlaşması için temel hedefler belirlemiştir.

Bunlar,

1. Politika hedefi: Uygulanabilirse, ulusal geleneksel tıp politikaları ve programları geliştirerek, geleneksel tıbbı ulusal sağlık sistemine dahil edilmesi,

2. Güvenlik, etkinlik ve kalite hedefi: Bilgi tabanını büyüterek ve yasal düzenleme ile kalite güvence standartları hakkında rehberlik sağlayarak geleneksel tıbbın güvenlik, etkinlik ve kalitesini arttırılması,

3. GETAT hizmetlerini ve kişisel sağlık hizmetlerini ulusal sağlık sistemlerine entegre ederek evrensel sağlık sigortasını teşvik etmek - geleneksel tıbbın ulaşılabilirliğini ve maliyetinin karşılanabilirliğini fakir nüfusun erişmesine önem vererek artırılması,

4. Gerçekçi kullanım - uygun geleneksel tıp yönteminin uygulayıcılar ve hastalar tarafından tedavide sonuç verecek şekilde kullanımını artırılması.

$\mathrm{Bu}$ stratejinin tüm dünyada uygulanmasındaki belirgin ilerlemeye rağmen, Üye Devletler aşağıda belirtilen konularla ilgili zorluklar yaşamaya devam etmektedirler:

- $\quad$ Politika ve yasal düzenlemelerin geliștirilmesi ve uygulatılması, 
- $\quad$ Entegrasyon, özellikle geleneksel tıbbın ulusal ve ilk basamak sağlı sistemine entegre olması için strateji ve kriterlerin belirlenmesi ve değerlendirilmesinde,

- Güvenlik ve kalite, özellikle ürün ve hizmetlerin değerlendirilmesi, uygulayıcıların yeterlilikleri, etkinliğ $\mathrm{i}$ değerlendirmede metodoloji ve kriterler,

- Geleneksel ve tamamlayıcı tıp reklam ve iddialarını kontrol ve düzenleme yeteneği,

- Geleneksel ve tamamlayıcı tıp uygulayıcılarının eğitim ve yetiştirilmesi,

- Politikalar, düzenlemeler, hizmet profilleri ve araştırma verisi bilgilerinin paylaşılması ya da hastalar için tarafsız ve güvenilir bilgi kaynaklarının tespit edilmesi gibi bilgi ve iletişim konuları,

$\mathrm{Bu}$ yeni strateji bahse konu zorlukları ele almayı hedeflemektedir. Bu da, Üye Devletlerin geleneksel ve tamamlayıcı tıp ile ilgili kendi ulusal durumlarını tespit etmesini ve sonrasında gerçek durumu yansıtacak şekilde politika, düzenleme ve prensiplerin geliştirilmesi ve uygulatılmasını gerektirmektedir. Üye Devletler aşağıdaki üç stratejik sektörde faaliyetlerini düzenlemek suretiyle bu zorlukları aşabilir:

1. Geleneksel ve tamamlayıcı tıbbın rolünü ve potansiyelini anlayacak ve tanıyacak uygun ulusal politikalarla aktif olarak yönetilebilmesine izin verecek bilgi tabanını oluştur

2. Geleneksel ve tamamlayıcı tıbbın kalite güvence, güvenlik, uygun kullanım ve etkin kullanımını, geleneksel ve tamamlayıcı tıp eğitim ve öğretimi, yetenek geliştirilmesi, hizmet ve tedavileri yoluyla ürünleri, uygulamaları ve uygulayıcıları düzenleyerek güçlen$\operatorname{dir}$

3. Geleneksel ve tamamlayıcı tıp hizmetlerini kapsayan sağlık hizmetinin verilmesi ve öz sağlık bakımına entegre ederek, sağlık hizmetleri ve sağlık sonuçlarının iyileştirilmesi için bu hizmetlerin potansiyel katkısına vurgu yaparak ve kullanıcıların kendi öz sağlık bakım seçenekleri konusunda bilgilendirilmelerini temin ederek, genel sağlık sigortasını teşvik et. Strateji, her hedef için, Üye Devletlere, partnerlere, paydaşlara ve WHO'ya rehberlik etmek üzere bir dizi faaliyeti belirlemektedir. Strateji, kendi ulusal kapasiteleri, öncelikleri, ilgili yasal düzenlemeleri ve şartları doğrultusunda bir stratejik plan tasarlamaları ve uygulamaları konusunda Üye Devletleri desteklemektedir. Hedefi, Üye Devletlere, etkin hizmet sağlanması, uygun yasal düzenleme ve politika geliştirilmesinin desteklenmesi ve bu ürün ve uygulamaların güvenli bir şekilde yapıldığının sağlanması maksadıyla ihtiyaçlarını tespit etmeleri ve önceliklendirmelerine yardım etmektir.

Ülkemizde de Geleneksel ve Tamamlayıcı Tip Uygulamaları Daire Başkanlığımız, ulusal ve uluslararası işbirlikleri ile ülkemizdeki geleneksel ve tamamlayıcı tıp uygulamalarını geliştirmek amacıyla 21/06/2012 tarihinde resmi olarak kurulmuş olup, bu alanda bilimsel platformu güçlendirmek, hali hazırda, sağlık alanı ile ilişkili olmayan kişiler tarafından da kontrolsüz bir şekilde kullanılabilen birçok yöntemin, çeşitli yasal düzenlemelere ve kontrole tabi olmasının ve sağlığın geliştirilmesine katkıda bulunma potansiyeli taşıyanların bilimsel metotlarla araştırılarak mevcut sağlık sistemi ile entegrasyonu sağlamak, Dünya Sağlık Örgütü, Avrupa Birliği ile çalışmalar yürüterek ülkemizde kanıta dayalı geleneksel ve tamamlayıcı tıp uygulamalarını yaygınlaştırmak, tanıtmak ve geliştirilmesine imkan tanıyarak, toplumun yaşam kalitesini arttırmak gibi misyonları üstlenmiştir.

Sağlık Bakanlığı 2014 yılı başında Geleneksel, Tamamlayıcı ve Alternatif Tıp Uygulamaları Yönetmeliği Taslağını hazırlamış ve ilgilenen kurumlardan görüşlerini 28 Şubat 2014 tarihine kadar iletmelerini istemiştir. Gerek yurt içi gerekse yurtdışı bilimsel kurulların da görüş ve önerileri doğrultusunda Geleneksel ve Tamamlayıcı Tip Uygulamaları Yönetmeliği, 27 Ekim 2014 tarihinde 29158 sayı ile Resmi Gazetede yayımlanarak yürürlüğe girmiş. Bu tarihten itibaren yüzyıllardır bilinen ve halk arasında kullanılan birçok geleneksel yöntem bilimin ışı̆̆ında geliştirilmeye başlanmış ve kanıta dayalı uygulamalara dönüşme şansını 
bulmuştur. $^{10}$

$\mathrm{Bu}$ yönetmeliğge göre bakanlık tarafından yalnızca hekimlere ve sadece kendi alanında uygulama yapmak üzere diş hekimlerine yetki verilmiştir. Bu sayede yetkin olmayan kişiler tarafından hatalı uygulamaların önüne geçilmesi amaçlanmıştır. Maalesef ülkemiz tıp fakültelerinde lisans ve sonrası dönemde geleneksel ve tamamlayıcı tıp ile ilgili bir eğitim verilmemekte idi. Bu da hekimlerin bu konudan uzak kalmasına yok açmakta idi. Böylece bu uygulamalar tıp dışı insanların ya da tıp mensubu olmakla birlikte bu konuda yeterli eğitimi almamış insanlar tarafından uygulanmaya çalışılmaktadır. Öncelikli olarak geleneksel ve tamamlayıcı tıp uygulamalarının bilimsel yöntemlerle araştırmalarının yapılması ve tıp doktorlarına lisans süresinde ve mezuniyet sonrası dönemde kanıta dayalı bilgiler eşliğinde uygulamalı bir şekilde öğretilmesi sağlanmalıdır. Tip ve Diş Hekimliği Fakültelerinde lisans ve lisansüstü programlarda Geleneksel ve Tamamlayıcı Tıp ile ilgili dersler yer alması, ilgili müfredatların oluşturulması yakın zamanda gerçekleşecektir. Bu gelişmeler olana kadar Sağlık Bakanlığı oluşturduğu Geleneksel ve Tamamlayıcı Tıp Yönetmeliği ile bu konulardaki mezuniyet sonrası dönemde verilebilecek eğitimleri tanımlamıştır.

$\mathrm{Bu}$ eğitimlere hekim, diş hekimi ve eczacı ve bazı özel meslek gruplarının katılabileceği belirli eğitim programları dahilinde kursların tanımı yapılmıştır. Bu kursların sonucunda Sağlık Bakanlığı Sertifikalı Eğitim Yönetmeliği dahilinde başarılı olan kursiyerlere verilen sertifikalar ile kursiyerlere bu tanı ve tedavi yöntemlerini uygulama yetkisi verilmektedir. Eğitimler sağlık bakanlığı SERTİFİKALI EĞİTİM YÖNETMELİĞİ kapsamında sağlık bakanlığı tarafında onaylı Üniversiteler bünyesindeki eğitim merkezleri tarafından verilmektedir.

Eğitimlerin tamamına hekimler katılabilmekte iken diğer sağlık meslek mensuplarının bazı eğitimlere katılmalarına izin verilmektedir. Bazı özel alanlar diş tabibi ve diğer sağlık meslek mensuplarının da (örneğin; homeopati için diş hekimleri ve eczacılar; hipnoz için diş hekimleri ve klinik psikologlar; sülük, kupa, ozon, mezoterapi, akupunktur, proloterapi, fitoterapi için diş hekimleri; müzikterapi için müzik lisans mezunları ve sağlı meslek mensupları vb) katılımına açıktır.

$\mathrm{Bu}$ kapsamda 14 farklı alanda eğitim tanımlanmıştır. $\mathrm{Bu}$ alanlar;

Fitoterapi (Bitkilerle Tedavi)
Akupunktur
Kupa Terapi
Sülük Tedavisi
Hipnoz
Ozon Terapi
Mezoterapi
Apiterapi
Proloterapi
Osteopati
Refleksoloji
Homeopati
Larva Uygulamasi
Müzik Terapi

Eğitimlerin verildiği Uygulama Merkezi; ilgili alanda sertifikası bulunan tabip ve/veya diş tabibi sorumluluğunda ve bu Yönetmelikte belirlenen uygulamaları yapmak üzere eğitim ve araştırma hastanesi ve tıp fakültesi veya diş tabipliği fakültesi sağlık uygulama ve araştırma merkezi bünyesinde kurulan ve Bakanlıkça yetkilendirilmesi halinde eğitim verilebilecek merkezi olarak tanımlanmıştır.

Eğitimler yüz yüze eğitim ( senkron ve asenkron olmak üzere ) ve uzaktan eğitim şeklinde verilmektedir.

1. Eğitim programı teorik ve uygulamalı olarak gerçekleştirilir. Eğitimin teorik bölümü örgün veya yaygın uzaktan eğitim şeklinde yürütülebilir.

2. Teorik eğitimin en fazla \% 80 ' i yeterli teknik alt yap1ya sahip eğitim merkezlerince uzaktan eğitim olarak verilebilir. 
3. Uzaktan eğitimde katılımcıların sunucu tarafından sağlanan alt yapı ile senkron ve asenkron bir şekilde internet üzerinden etkileşimli uygulamalara erişmesi sağlanacak, canlı ders programı dahilinde belli bir salonda belli saatlerde enteraktif, canlı dersler gerçekleştirilecektir.

4. Katılımcının eğitim süresince eğitime göre farklı sayılarda vakanın tedavisini üstlenerek takip etmesi gereklidir.

5. Katılımcılar uygulama eğitimlerini akupunktur polikliniklerinde/merkezlerinde uygulamaları birebir veya küçük gruplar halinde hasta başında sırasıyla; "izleme", "gözlem altında yapma" ve" bağımsız düzeyde yapma” aşamalarına göre gerçekleștirir.

6. Ders içerikleri eğitim programının başında belirtilir, kaynak gösterilir veya ders notları verilir

7. Teorik ve uygulamalı dersler günde en çok 8 (sekiz) ders saati olacak şekilde yapılır. Bir ders saati süresi 40 (kırk) dakikadır.

8. Bir eğitim döneminde Bakanlıkça görevlendirilecek 1 (bir) katılımcı dışında eğitime göre değişmekle birlikte 25 ile 30 sayıda katılımcı eğitime alınabilir.

9. Bakanlıkça görevlendirilecek katılımcı Devlet Hizmet Yükümlülüğü bulunmayan, çalıştı̆̆ kurumda vereceği hizmet gereği bu programda alacağ arz eden Tabip veya Diş Tabibi olacaktır. Bu katılımcılardan eğitim ücreti alınmayacaktır.

10. Katılımcılar eğitim programı sırasında başka bir alanda/birimde/merkezde veya başka bir işte çalıştırılamazlar.

11. Eğitime kesintisiz devam esas olup uygulama eğitimine devam zorunludur. Yasal mazereti nedeniyle uygulama eğitiminin en fazla \%10' una katılmayan katılımcılar eğitime katılmadıkları süreyi tamamlamadıkları sürece sertifika sınavına alınmaz. Teorik eğitime ise yasal mazereti nedeniyle en fazla \% 10 devamsızlık yapılabilir.

12. Eğitim programında aşağıdaki öğretim ve öğrenme, strateji, yöntem ve teknikler uygulanır:

- Sözlü anlatım yöntemi
- Video ile öğretim yöntemi

- Küçük grup tartışması

- Uygulamaları göstererek yaptırma

- $\quad$ Soru-cevap yöntemi

- $\quad$ Simülasyon yöntemi

- $\quad$ Klinik uygulama

\section{Eğitim Süreleri;}

Fitoterapi (Bitkilerle Tedavi): 280 saat (162 saat teorik 80 saat pratik 28 laboratuar) (diş hekimleri için 138 sa. teo. 38 sa. labor. 39 sa. Pratik)

Akupunktur : 500 saat (300 sa. teorik 200 sa. pratik) (diş hekimleri için 300 sa. teorik 100 s pratik )

Kupa Terapi: 120 saat ( 50 saat teorik 70 saat pratik )

Sülük Tedavisi: 120 saat ( 50 saat teorik 70 saat pratik)

Hipnoz: 120 saat ( 50 saat teorik 70 saat pratik )

Ozon Terapi: 120 saat ( 50 saat teorik 70 saat pratik)(diş hekimleri için 32 teorik 28 pratik )

Mezoterapi: 120 saat (50 saat teorik 70 saat pratik)

Apiterapi: 120 saat (50 saat teorik 70 saat pratik)

Proloterapi: 120 saat (50 saat teorik 70 saat pratik)

Osteopati: 120 saat (50 saat teorik 70 saat pratik)

Refleksoloji: 120 saat (50 saat teorik 70 saat pratik)

Homeopati: 350 saat (220 saat teorik 130 saat pratik)

Larva Uygulaması: 120 saat (50 saat teorik 70 saat pratik)

Müzik Terapi: 120 saat (50 saat teorik 70 saat pratik)

\section{EĞİTÍCILLER VE NİTELİKLERİ}

Aşağıdaki şartlardan herhangi birine haiz olanlar eğitici olarak görevlendirilir.

1. Müfredatta yer alan derslerin konuları ile ilgili anabilim/bilim dalları öğretim üyeleri ilgili uzman tabipler

2. Eğitim vereceği konuda en az 3 (üç) adet ulusal ya da uluslararası hakemli bilimsel dergilerde yayımlanmış makalesi olan tabip, diş tabipleri ve eczacılar,

3. Bakanlıkça onaylanmış “ Uygulama Sertifikası”na sahip, alanında aktif olarak çalışan tabipler ve diş tabipleri

4. Yabancı uyruklu olup, uluslararası platformda ilgili 
eğitimi aldığını ve ilgili alanda aktif olarak çalıştığını belgeleyen ve ilgili birimce kurulan komisyon tarafından yeterliliği uygun görülen kişiler,

5. Ana ders konusu harici diğer konular için; alanlarında uzman veya akademisyenler, Uygulama Merkezleri, eğitici isim ve niteliklerini Sağlık Bakanlığına bildirmekle yükümlüdür.

Eğitimin Değerlendirilmesi (Sınav usulü, başarı ölçütü, ek sinav hakkı vs.)

Eğitimin değerlendirilmesi aşağıdaki usul ve esaslara göre yapilacaktır.

1. Devam zorunluluğunu yerine getirmeyen katılımcılar sinava alınmaz

2. Eğitim programı sonunda teorik sınav ve uygulama sinavi yapılır.

3. Teorik sınav soruları program sorumlusunun başkanlığında en az üç eğitimciden oluşan sınav komisyonu tarafından eğitimin içeriğinde yer alan konuların tamamını kapsayacak şekilde çoktan seçmeli olarak hazırlanır.

4. Katılımciların hem teorik sınavdan hem de uygulama sınavından ayrı ayrı başarılı olması gerekir.

5. Başarılı sayılabilmek için 100 (yüz) üzerinden en az 70 (yetmiş) puan almış olmak gerekir. Teorik sınavdan başarılı olamayan katılımcılar uygulama sınavına alınmaz.

6. Teorik sınavda başarısız olan adaylara en fazla 2 (iki) kez daha teorik sınava girme hakkı tanınır, başarısız olanların sertifikalı eğitim programına tekrar başvurması gerekir.

7. Uygulama sınavı, hasta başında ve/veya maket üzerinde uygulama yapmak suretiyle yapilır.

8. Uygulama sınavları Sertikalı Eğitim Programı Uygulama Değerlendirme Formu (EK1) kullanılarak yapılır. Formda yer alan her bir konu; Oldukça Yeterli (4), Yeterli (3), Kismen Yeterli (2), Yetersiz (1) ve "Değerlendirilemedi" (0) derecelerinden biri ile değerlendirilir. Formda yer alan konuların her birinden alınan puanların toplamı bulunur. Bu toplam değerlendirilen konu sayısına bölünerek ortalama puan bulunur. $\mathrm{Bu}$ ortalama puan 25 (yirmi beş) sayısı ile çarpılarak 100 (yüz) puan üzerinden hesaplanır. 100 (yüz) puan üzerinden 70 (yetmiş) puan alan katılımcı uygulama sınavından başarılı sayılır.

9. Uygulama sınavında; Tedavi planlaması, ilgili tedavinin uygulanması, Tedavi öncesi ve sonrası takip uygulamaları değerlendirilecektir.

10. Sertifikalandırma için katılımcının başarı puanı teorik sınavda alınan puan ile uygulama sınavında alınan puanın aritmetik ortalaması alınarak hesaplanır.

11. Uygulama sınavından başarısız olan katılımcılara en fazla 2 (iki) kez daha sınava girme hakkı tanınır, başarısız olan katılımcıların Sertifikalı Eğitim Programına tekrar başvurması gerekir.

12. Sertifikalı Eğitim Programı sonunda sertifikalandırma için yapılan teorik ve uygulama sınavı notlarına itiraz eden katılımcıların itirazları sertifikalı eğitim uygulayıcıları tarafından en geç 5 (beş) iş günü içerisinde değerlendirilerek sonuçlandırılır.

13. Teorik ve uygulama sınavında başarılı olan katılımcı sertifika almaya hak kazanır.

14. Sertifika, Sağlık Bakanlığı tarafından tescil edilir ve geçerlilik kazanır.

\section{SERTİFİKANIN GEÇERLİLIKK SÜRESI}

Sertifikanın geçerlilik süresi 7 yıldır.

\section{SERTIFİKANIN YENİLENME ÖLÇÜTLERİ}

Sertifikanın yenilenmesi aşağıdaki usul ve esaslara göre yapilir.

1. Sertifikaların geçerlilik süresi sonunda sertifika sahiplerinden;

- $\quad$ a. Sertifikayı aldıktan sonra sertifika geçerlilik süresi içerisinde en az 4 (dört) kezf ilgili ulusal / uluslararası eğitimlere veya bilimsel toplantılara katıldığını belgeleyenler veya 2 (iki) adet ulusal / uluslararası hakemli dergide ilgili konuda yayın yapmış olanların ya da aktif olarak bu alanda 2 (iki) yıl süre ile çalıştığını bel- 
gelemiş olanların sertifikaları yenilenir. Sertifika sahipleri bu kriterlerle ilgili belgelendirmelerini yenileme başvurusu sırasında sertifikayı aldıkları sertifikalı eğitim uygulayıcılarına sunacaklardır.

- b. Birinci maddedeki şartlardan birini sağlayamayan sertifika sahiplerinin ise sertifika yenileme sınavına katılması gerekir

2. Yenileme sınavı Bakanlık ilgili biriminin koordinasyonunda sertifikalı eğitim programı uygulayıcıları tarafından ilgili eğitim programının içeriğinde yer alan konular ve alandaki güncel gelişmeler doğrultusunda çoktan seçmeli olarak hazırlanan sorulardan teorik sınav şeklinde yapılır.

3. Yenileme sınavdan 70 (yetmiş) ve üzeri puan alan katılımcılar başarılı sayılır ve sertifika süreleri 5 (beş) yıl daha uzatilır.

4. Sertifika yenileme sınav süreci tamamlanıncaya kadar sertifika sahiplerinin sertifikaları geçerlidir.

5. Hukuken kabul edilebilir mazeret halleri dışında sertifika yenileme sınavına peş peşe iki kez katılmayanların sertifikaları geçersiz sayılır. Hukuken kabul edilebilir mazeretinin sona ermesini takiben en kisa sürede sınava alınır.

6. Sertifikalı eğitim programı uygulama yetkisi verilen yerin herhangi bir sebeple eğitim faaliyetlerinin durması ve sertifikalı eğitim uygulama yetki belgelerinin iptal edilmesi ya da kapatma ve devir durumlarında sertifika yenileme sınavları Bakanlığın ilgili birimince yapilır.

7. Sertifika yenileme sınavında başarısız olan sertifika sahiplerinin yenileme sınavı notlarına itirazları sertifika yenileme sınav komisyonu tarafından en geç 5 (beş) gün içerisinde değerlendirilerek sonuçlandırılır.

\section{DENKLİK İŞLEMLERİNINN USUL VE ESASLARI}

Denklik Başvurusu Sağlık Bakanlığı Sertifikalı Eğitim Yönetmeliği hükümleri doğrultusunda Bakanlıkça hazırlanan denklik başvuru formu (EK-3) kullanılarak denklik talebinde bulunulur. Bu formda belirtilen tüm belgelerin sunulması zorunludur. $\mathrm{Bu}$ formda belirlenen her bir başlığın altı ayrıntıları ile birlikte doldurulacak, eğitimin verildiği kurum / kuruluşça onaylanmış ve aşağıda belirtilen belgelerin aslı, eğitim yurt dışında alınmış ise ayrıca belgelerin yeminli mütercim tarafından Türkçeye çevirisi formunun ekinde dosya halinde sunulacaktır.

Başvuru Formu Ekinde Yer Alacak Belgeler: Denklik başvurusunda aşağıdaki belgeler istenir:

1. Sertifikanın noter tasdikli sureti.

2. Tıp Fakültesi/Diş hekimliği Fakültesi diplomasının noter tasdikli sureti.

3. Varsa lisansüstü eğitimi bitirme belgesinin noter tasdikli sureti.

4. T.C. nüfus cüzdanı fotokopisi, yabancı uyruklu kimlik kartı ve 2 adet fotoğraf.

5. Başvuru Formunun 4 üncü maddesinde yer alan eğitim müfredatı ile ilgili tüm bilgi ve belgeler. (Eğitimin alındığı ya da belgenin düzenlendiği dilde belgenin aslı ve Türkçe tercümesi olacak.)

6. Eğitim müfredatı ile birlikte tabipler mevzuatta belirtilen ders saatlerine eşit veya üstü ders eğitim aldığını gösterir belge.

7. Başvuru formunun 3 üncü maddesinde yer alan ve eğitimin alındığı kurum / kuruluş / özel hukuk tüzel kişisi / gerçek kişisinin eğitim alınan ülkenin resmi sağlık otoritesi ve o ülkedeki Türkiye misyon şefliğinden eğitim veren kurumun yetkili olduğunun belgelenmesi istenecektir.

8. Eğitim gördüğü ülkede en az eğitim süresi boyunca ikamet edildiğinin pasaportla veya diğer resmi belgelerle belgelenmesi ve resmi görevlilerin o süre içerisinde izinli olduğunu gösterir belge istenecektir.

Denklik İşlemlerinin Yapılışı Denklik işlemleri aşağıdaki şekilde yapılır:

1. Sertifika denkliği için müracaat edenlerin başvuru dosyaları ilgili birimce oluşturacak bilim komisyonu tarafından sertifikalı eğitim programı standartları doğrultusunda incelenir

2. Dosyaları uygun ve yeterli bulunan başvuru sahipleri 
teorik ve uygulamalı sınava alınır.

3. Teorik sınavdan 100 (yüz) üzerinden 70 (yetmiş) ve üstü puan alan adaylar başarılı sayılır. Teorik sınavda başarısız olan adaylara en fazla 2 (iki) kez daha teorik sınava girme hakkı tanınır, bu sınavlarda da başarısız olan adayları sertifikalı eğitim programına başvurmas1 gerekir.

4. Teorik sınavdan geçemeyen katılımcılar uygulama sınavina alınmaz.

5. Uygulama sınavında 100 (yüz) üzerinden 70 (yetmiş) ve üstü puan alan adaylar başarılı sayılır. Uygulama sınavından başarısız olan adaylara 2 (iki) kez daha uygulama sınavına girme hakkı tanınır, bu sınavlarda da başarısız olan adayların Sertifikalı Eğitim Programına başvurması gerekir.

6. Teorik ve uygulama sınavında başarılı olan adaylara sertifika denklik belgesi düzenlenir.

7. Sertifika Denklik Belgesi, Sağlık Bakanlığı tarafından tescil edilir.

8. Yüksek Lisans / Doktora Denkliği Yönetmelik yayımlanmadan önce alanında yüksek lisans / doktora derslerini almış olan tabip / diş tabipleri bir defaya mahsus olmak üzere transkriptleri ve belgeleri incelenerek eksik kalan konu ve alanlar tamamlanmak kaydı ile sertifika verilir.

Eğitimler Sağlık Bakanlığı Geleneksel Tamamlayıcı Tıp Müfredatında belirtilen esaslara uygun olarak Üniversite ve Eğitim Araştırma Hastaneleri bünyesinde kurulan Geleneksel ve tamamlayıcı Tıp Araştırma ve uygulama merkezlerinde (GETAT) verilmektedir. Sağlık Bakanlığına bağlı hastaneler bünyesinde 32 adet uygulama merkezi ve 21 adet üniversite bünyesinde uygulama merkezi bulunmaktadir.

Bunlar;

- Adnan Menderes Üniversitesi GETAT Uygulama Merkezi

- $\quad$ Ankara Yıldırım Beyazıt Üniversitesi GETAT Merkezi

- Ankara Yıldırım Beyazıt Üniversitesi Yenimahalle
Eğitim ve Araştırma Hastanesi GETAT Uygulama Merkezi

- $\quad$ Atatürk Üniversitesi GETAT Uygulama Merkezi

- $\quad$ Balıkesir Üniversitesi GETAT Uygulama Merkezi

- Başkent Üniversitesi GETAT Uygulama Merkezi

- Bezmialem Vakıf Üniversitesi GETAT Uygulama Merkezi

- $\quad$ Cumhuriyet Üniversitesi GETAT Uygulama Merkezi

- Düzce Üniversitesi SUAM GETAT Merkezi

- $\quad$ Ege Üniversitesi GETAT Uygulama Merkezi

- $\quad$ Firat Üniversitesi GETAT Uygulama Merkezi

- Gazi Üniversitesi GETAT Uygulama Merkezi

- Hacettepe Üniversitesi GETAT Uygulama Merkezi

- Harran Üniversitesi GETAT Uygulama Merkezi

- İnönü Üniversitesi Geleneksel ve Tamamlayıcı Tip Uygulama Merkezi,

- İstanbul Biruni Üniversitesi GETAT Uygulama Merkezi

- İstanbul Medipol Üniversitesi GETAT Uygulama Merkezi

- İstanbul Yeditepe Üniversitesi GETAT Uygulama Merkezi

- Konya Necmettin Erbakan Üniversitesi Meram Tip Fakültesi GETAT Uygulama Merkezi

- Konya Selçuk Üniversitesi GETAT Uygulama Merkezi

- Namik Kemal Üniversitesi SUAM GETAT Uygulama Merkezi

Sağlık Bakanlığına Bağlı Uygulama Merkezleri ise

- T.C. Sağlık Bakanlığı Darıca Farabi Eğitim ve Araştırma Hastanesi

- T.C. Sağlık Bakanlığı Haydarpaşa Numune Eğitim ve Araştırma Hastanesi

- T.C. Sağlık Bakanlığı Elazığ Fethi SEKİN Şehir Hastanesi GETAT Uygulama Merkezi

- $\quad$ T.C. Sağlık Bakanlığı Kayseri Şehir Hastanesi GETAT Uygulama Merkezi

- T.C. Sağlık Bakanlığı Prof.Dr. Mazhar Osman Ruh Sağlığı ve Hastalıkları Eğitim ve Araştırma Hastanesi GETAT Uygulama Merkezi 
- $\quad$ T.C. Sağlık Bakanlığı Adıyaman Eğitim ve Araştırma Hastanesi GETAT Uygulama Merkezi

- T.C. Sağlık Bakanlığı Eskişehir Şehir Hastanesi GETAT Uygulama Merkezi

- Dr. Abdurrahman Yurtaslan Onkoloji Eğitim ve Araştırma Hastanesi Geleneksel ve Tamamlayıcı Tip Uygulama Merkezi

- Abant İzzet Baysal Fizik Tedavi ve Rehabilitasyon Eğitim ve Araştırma Hastanesi GETAT Uygulama Merkezi

- $\quad$ SBÜ Van Eğitim ve Araştırma Hastanesi GETAT Uygulama Merkezi

- $\quad$ SBÜ Diyarbakır Gazi Yaşargil Eğitim ve Araştırma Hastanesi GETAT Uygulama Merkezi

- $\quad$ SBÜ Ankara Numune Eğitim ve Araştırma Hastanesi GETAT Uygulama Merkezi

- $\quad$ SBÜ Ankara FTR Eğitim ve Araştırma Hastanesi GETAT Uygulama Merkezi

- SB Ahi Evran Üniversitesi Eğitim ve Araştırma Hastanesi

- Etlik Zübeyde Hanım Kadın Hastalıkları Eğitim ve Araştırma Hastanesi

- Şişli Eğitim ve Araştırma Hastanesi GETAT Uygulama Merkezi

- Alaaddin Keykubat Üniversitesi Alanya Eğitim ve Araştırma Hastanesi GETAT Uygulama Merkezi

- Aksaray Üniversitesi Aksaray Eğitim ve Araştırma Hastanesi GETAT Merkezi

- Sakarya Üniversitesi Sakarya Eğitim ve Araştırma Hastanesi GETAT Uygulama Merkezi

- Ankara Dr. Zekai Tahir Burak Kadın Sağlığı ve Hastalıkları Eğitim ve Araştırma Hastanesi GETAT Uygulama Merkezi

- Gaziler Fizik Tedavi ve Rehabilitasyon Eğitim ve Araştırma Hastanesi GETAT Uygulama Merkezi

- $\quad$ Niğde Ömer Halisdemir Üniversitesi Eğitim ve Araştırma Hastanesi

- Karabük Eğitim ve Araştırma Hastanesi GETAT Uygulama Merkezi
- $\quad$ Elazığ Eğitim ve Araştırma Hastanesi GETAT Uygulama Merkezi

- İzmir Katip Çelebi Üniversitesi Atatürk Eğitim ve Araştırma Hastanesi GETAT Uygulama Merkezi

- İzmir Bozyaka Eğitim ve Araştırma Hastanesi GETAT Merkezi

- İstanbul Bağcılar Eğitim ve Araştırma Hastanesi GETAT Merkezi

- İstanbul Ümraniye Eğitim ve Araştırma Hastanesi GETAT Uygulama Merkezi

- Antalya Eğitim ve Araştırma Hastanesi GETAT Uygulama Merkezi

- Ankara Eğitim ve Araştırma Hastanesi GETAT Uygulama Merkezi

- Keçiören Eğitim ve Araştırma Hastanesi GETAT Uygulama Merkezi

- Ankara Gülhane Eğitim ve Araştırma Hastanesi GETAT Uygulama Merkezi

\section{EĞİTİM VERİLECEK YERİN NITTELIKKLERİ}

Teorik ve Uygulama Eğitimi İçin Gerekli Donanım Özellikleri:

1. Uzaktan Eğitim için:

- a. Uluslar arası öğrenme içerik standardı (Scorm, AlCC vb.) uyumlu Öğrenme Yönetim Sistemi (ÖYS) yazılımı olması,

- b. Öğrenme Yönetim Sistemi (ÖYS) Yönetim paneli olması,

- c. Öğrenci kapasitesine uygun sunucu ve altyapı mimarisi olması,

- d. Eş zamanlı eğitimlerin sunulması için video konferans yazılım ve alt yapılarının sisteme entegre edilmesi,

2. Katılımcıların enteraktif eğitim alabilecekleri yeterli donanıma sahip eğitim salonu olması,

3. Eğitime alınacak katılımcı sayısına uygun yeterli ısı ve ışığa sahip, havadar ve modüler sitemin kullanılabileceği ve gerektiğinde iki ayrı salona dönüşebilen bir yapıda eğitim salonu olması, 
4. Katılımcı sayısına göre uygun ve yeterli masa-sandalyenin bulunmas1,

5. Uzaktan eğitim için öğrenci kapasitesine uygun sunucu ve altyapı mimarisi olması,

6. Eş zamanlı eğitimlerin sunulması için video konferans yazılım ve alt yapılarının sisteme entegre edilmesi,

7. Bakanlıkça açılmasına izin verilmiş Geleneksel ve Tamamlayıcı Tip Uygulamaları Merkezi olması,

8. Eğitimin uygun teknoloji ile yapılmasına olanak sağlayacak gerekli bilgisayar, görsel-işitsel araçlar, uygulama maketleri, yazı tahtası, eğitim hedeflerinin, konu ve içeriklerinin / sunumların katılımcılara verilmesini sağlayabilecek baskı / yazıcı, fotokopi, kağıt destek sistemleri, eğitim salonunda tercihen online görsel animasyonların / eğitim materyallerinin kullanılabileceği internet bağlantısı vb. olması gereklidir.

Yukarıda bahsedilen, Sağlık Bakanlı̆̆ı'nca yayımlanan son yönetmelik geleneksel ve tamamlayıcı tıp alanda eğitimlerde bir standardizasyon sağlamayı ve önceki yıllarda yetkin olmayan kişiler tarafından yapılan yanlış uygulamaların önüne geçilmesini amaçlamaktadır. Bu yönetmelik ile hekim dışındaki kişiler yapılan uygulamaları önlenmekte, konu ile ilgili eğitimlere ve eğitim veren kuruluşlara belirli bir düzenleme getirilmekte, hangi yöntemlerin hangi durumlarda uygulanabileceği -sınırlılıkları ile birlikte- belirtilerek, bu alanı düzenlemeye yönelik önemli bir adım atılmaktadır.

Geleneksel ve tamamlayıcı tıp uygulamalarının ülkemizde yaygınlaşması ile birlikte toplumun ve hekimlerin bu alana ilgisi artmıştır. Bu da bu konuda yeterli sayıda olmayan araştırmalara yenilerinin eklenmesi mecburiyetini doğurmaktadır. Bu konuda yapılacak araştırmalarla ilgili mevzuatların oluşturulması süreci devam etmektedir.

Akupunktur, fitoterapi gibi bazı geleneksel ve tamamlayıc1 tıp uygulamalarında dünya üzerinde de birçok çalışma bulunmaktadır ancak homeopati, apiterapi, refleksoloji gibi uygulamalarda dünyada ve ülkemizde yeterli sayıda çalışma bulunmamaktadır. Tüm bu alanlarda yapılacak çalışmaların desteklenmesi gerekmektedir. Araştırmalar ve uygulamalar sırasında kullanılan ürünlerin ruhsatlanması, üretimi, kontrolü ve piyasa denetimi konularında diğer sektörlere de rol düşmektedir.

Ülkemizde bu alanın denetim dışı ve sahipsiz bırakılmaması gerekmektedir. Ancak, bu alanının düzenlenip mevzuata uygun bir şekilde işlemesini sağlamak gerektirmektedir.

Ülkemizdeki bu gelişmeler dünya genelinde de takip ve takdir edilmektedir. Ülkemize yaptığı bir ziyaret sonrasında DSÖ Avrupa Bölgesi Direktörü Dr. Zsuzsanna Jakab, geleneksel ve tamamlayıcı tıp alanında daha fazla nasıl çalışma yapabileceklerini, geleneksel tıp sistemleriyle modern tıp sistemleri arasında nasıl bir entegrasyon sağlayabilecekleri konularını ele alacaklarını belirterek, " $\mathrm{Bu}$ konuda da faaliyetler yapmakla ilgili girişimlerimizi başlatacağız. Türkiye, bu noktada gerçekten çok şey öğrenebileceğimiz bir ülke. Bununla ilgili dünyanın çeşitli ülkelerinde bu çalışmalar var ve Türkiye bu alandaki örnek, model ülkelerden bir tanesi” demiştir.

Atılmış olan bu önemli adımların devamlılı̆̆ı da önem arz etmektedir. Bundan sonraki süreçte "Bilimsel Komisyon"un kurulması ve etkin bir şekilde işletilmesi gereklidir. Ayrıca her bir uygulama alanı farklı olduğundan, sağlıklı olarak sürecin işleyebilmesi için her bir alana yönelik alt komisyonların oluşturulması uygun olacaktır. Bunun yanı sıra, konu üzerindeki var olan kaygılar da dikkate alınarak, hekimleri bilgilendirici ve toplumu bilinçlendirici çalışmalar yapılması, yurtdışı örneklerinin özellikle Avrupa Birliği ve ABD'deki düzenleme ve hekim uygulamaların, bilimsel kongrelerle seviyeli tartışma ortamlarının oluşturulması ve araştırma yapmayı teşvik edecek adımların atılması önemlidir. Süreçte, tedavi ücretlerinin geri ödeme kapsamına alınması özelikle sağlık hizmetlerinde erişimde eşitlik ve hakkaniyet açısından çok önemli bir gelişme 
olacaktır.

Geleneksel ve Tamamlayıcı Tip Eğitimleri ülkemizde birçok üniversite bünyesinde Sağlık Bakanlığı Sertifikalı eğitim yönetmeliği kapsamında tanımlanın eğitimler bünyesinde devam etmekle birlikte. Sağlık Bilimleri Üniversitesi Sağlık Bilimleri Enstitüsü bünyesinde kurulan Geleneksel ve Tamamlayıcı Tip Anabilim Dalı yüksek lisans düzeyinde Tezli yüksek lisans ve doktora programları ile öğrenci kabul etmekte, eğitim vermektedir. Sonuç olarak, ilerleyen yıllarda Geleneksel ve tamamlayıcı tıp alanında model ülkelerden biri olan ülkemizde eğitimler ve araştırmalar yaygınlaşacak, araştırmalar sonucunda da Geleneksel ve Tamamlayıcı Tip yöntemleri kanıta dayalı tıp yöntemlerinden biri olarak tıp dünyasında hak ettiği öneme kavuşacaktır. 
Journal of BSHR 2019;3(Özel Sayı):1-12

\section{Kaynaklar}

1. General Guidelines for Methodologies on Research and Evaluation of Traditional Medicine, World Health Organization, 2000 Geneva

2. WHO Traditional Medicine Strategy 2002-2005, World Health Organization Geneva

3. Legal Status of Traditional Medicine and Complementary/Alternative Medicine: A Worldwide Review, World Health Organization, Geneva, 2001

4. Kopelman, Lorretta M. "The role of science in assessing conventional, complementary, and alternative medicines". In Callahan D. The Role of Complementary and Alternative Medicine: Accommodating Pluralism. Washington, DC: Georgetown University Press. 2004: pp. 36-53.

5. Traditional medicine, Fact sheet $N^{\circ} 134$ December 2008 http://www.who.int/mediacentre/ factsheets/fs134/en/index.html (Erişim tarihi: 5.01.2012)
6. NIH 'Estimates of Funding for Various Research, Condition, and Disease Categories (RCDC)' http://report.nih.gov/rcdc/categories/default.aspx

7. "White House Commission on Complementary and Alternative Medicine Policy". March 2002. Archived from the original on 2011-08-25.

8. "BeijingDeclaration" http://www.who.int/medicines/areas/traditional/congress/beijing declaration/en/index.html (Erişim tarihi: 5.01.2012)

9. Dr Margaret Chan, WHO Congress on Traditional Medicine, 7-9 November 2008, Beijing, China http://www.who.int/dg/speeches/2008/20081107/en/index.html (Erişim tarihi: 5.01.2012)

10. Salih Mollahaliloğlu, F. Gülçin Uğurlu, Mehmet Zafer Kalaycı, Dilek Öztaş, Geleneksel ve Tamamlayıcı Tip Uygulamalarında Yeni Dönem Ankara Med J, 2015, 15(2):102-105 